\title{
Kinetic Reaction of Tert-Butyl Glucoside Esterification with Oleic Acid using p-TSA Catalyst and Co-solvent tert-Butanol
}

\author{
I Gusti Ngurah Widiantara ${ }^{1 *}$, Bambang Pramudono ${ }^{1}$ \\ Department of Chemical Engineering, Faculty of Engineering, Diponegoro University, Semarang, 50239, Indonesia ${ }^{1}$
}

\begin{abstract}
Surfactants produced from oil and natural gas derivatives can cause environmental pollution because they produce waste that is difficult to degrade. So, it is necessary to develop surfactant production which does not pollute the environment, for example, Alkyl poly glucosides, here a new type of alkyl poly glucoside surfactant will be synthesized by reacting Tert-butyl Glucoside (TBG) with oleic acid to form Tert-butyl Oleil Glucoside (TBOG). The aim in this research is to determine the exact reaction kinetics model and the kinetics parameters of the Tert-butyl Glucoside (TBG) esterification reaction with oleic acid using p-TSA as catalyst and modification of the addition of organic co-solvent. The variables studied were the mole ratio (TBG: oleic acid), temperature, and \% catalyst. From observations, the best conditions were obtained at a mole ratio of $1: 4$, the temperature of $90^{\circ} \mathrm{C}$ and $2 \%$ catalyst. The best yield obtained was $91.49 \%$. Product quality was characterized by FTIR and GC-MS spectroscopy. The kinetics of esterification reaction of TBG with oleic acid using catalyst p-TSA and modification of the addition of organic co-solvent was carried out at 75 , $90,92^{\circ} \mathrm{C}$. The reaction kinetics parameters for the kinetics model with co-solvent are $\mathrm{A}_{1}{ }^{0}=6,10^{3} \mathrm{~L} / \mathrm{mol} . \mathrm{s} ; \mathrm{A}_{2}{ }^{\mathrm{o}}=1,3 \cdot 10^{1}$ $\mathrm{L} /$ mol.s; $-\mathrm{Ea} 1=-2.103,44 \mathrm{~J} / \mathrm{mol}$; $-\mathrm{Ea} 2=-1.446,63 \mathrm{~J} / \mathrm{mol}$. The reaction kinetics parameters for the kinetics model without the addition of co-solvent are $\mathrm{A}_{1}{ }^{0}=3,3.10^{1} \mathrm{~L} / \mathrm{mol} . \mathrm{s} ; \mathrm{A}_{2}{ }^{0}=1.5 \mathrm{~L} / \mathrm{mol} . \mathrm{s} ;-\mathrm{Ea} 1=3.683,93 \mathrm{~J} / \mathrm{mol} ;-\mathrm{Ea} 2=-$ $4.770,57 \mathrm{~J} / \mathrm{mol}$.
\end{abstract}

Keywords: Esterification, Kinetics Parameter, TBOG Surfactant, Co-Solvent

\section{INTRODUCTION}

Surfactants derived from petroleum and natural gas can cause environmental pollution because it was not easy to degrade after use, and also oil-based is a non-renewable source. From that problem, we need to develop new types of surfactants that are easily degraded and come from renewable sources [1]. Many studies on the synthesis of surfactants with carbohydrates as the primary raw material have been developed. The benefits of this surfactant are environmentally friendly (biodegradable) and non-toxic [2], [4]. As awareness of good health and the environment increases, demand for surfactants that were easy to degrade and vegetables also increases [5].

Alkyl Poly Glucoside Surfactant (APG) is a non-ionic surfactant that environmentally friendly. It synthesized from carbohydrate and fatty alcohol raw materials. Today, there had been many studies for producing APG surfactants that used sago [6], cassava [7], glucose and dodecanol [8], or brownish vegetable oil [9] as raw materials. Surfactants have hydrophilic groups and lipophilic groups. The numbers that show a comparison between hydrophilic and lipophilic groups are called Hydrophilic-Lipophilic Balance (HLB). The higher the HLB value of the surfactant showed more soluble in water, and the lower the HLB value of the surfactant showed more soluble in oil [10], [11]. TBOG surfactants are synthesized by reacting carbohydrates and fatty alcohol. Synthesis usually done in two stages, the first stage is the reaction of carbohydrate acetalization with alcohol, and the second stage is esterification with fatty acids.

In this research, a kinetics model of Terbutyl Glucoside (TBG) esterification reaction with oleic acid prepare using the help of p-TSA catalyst from the research conducted [15], and the supporting kinetics parameters. Then the correlation and comparison of the kinetic model determined using co-solvent and without co-solvent.

\section{A. Materials}

\section{EXPERIMENTAL DETAILS}

The materials used are oleic acid 99\% (Merck), benzene 99,7\% (Merck), p-TSA 98,5\% (Merck), $\mathrm{NaOH} 98 \%$ (Merck), sodium acetate $98 \%$ (Merck), sodium sulfate $98 \%$ (Merck) and ter-Butyl glucoside 49\% (made from the reaction of glucose and tert-butanol).

\section{B. Synthesis of Ter-Butyl Oleil Glucosides}

2,82 grams $(0,012 \mathrm{~mol}) \mathrm{TBG}$ and oleic acid (mole ratio varies) mixed into $500 \mathrm{ml}$ of three flask necks equipped with reflux condensers, thermometers, magnetic stirrers, and oil baths. The p-TSA catalyst (percent catalyst varies) added with $50 \mathrm{ml}$ of benzene as a solvent. All reactants are mixed and heated (temperature ranges). After that, it is cooled at room temperature, neutralized with 50\% sodium hydroxide, and stirred. After all, it purified by evaporation. The residue is a 
Vol. 6, Issue 12, December 2019

TBOG surfactant. Then the esterification reaction is modified by adding $2 \%$ co-solvent to the reactants. The esterification temperature variations for the reaction kinetics are 75, 90, and 92oC, with sampling times of 10, 30, 60, 75, and 100 minutes. The esterification results were analyzed using FTIR and GC-MS to determine the yield amount of synthesized products formed. Then the reaction kinetics parameter values are searched to determine the exact reaction kinetics model, and compare the effect of adding co-solvent to the synthesis product.

\section{RESULTS AND DISCUSSION}

\section{A. The Effect of Mole Ratio on Yield}

Based on previous research [15], the esterification process was carried out with various mole ratios, $2 \%$ catalyst (w/w), stirring $100 \mathrm{rpm}$, synthesis time 4 hours, and temperature of $95^{\circ} \mathrm{C}$ (Fig. 1). Figure 1 shows an increase in synthesis results from the 1: 2 to 1: 4-mole ratio, the higher the mole of oleic acid reacted, the greater the synthesis results obtained. It caused by a shift in reaction to the right. Because the esterification reaction between TBG and oleic acid is reversible, then at one point, the phase equilibrium will experience, this causes the synthesis results obtained to tend to be constant when it is at a mole ratio of 1:5 [17].

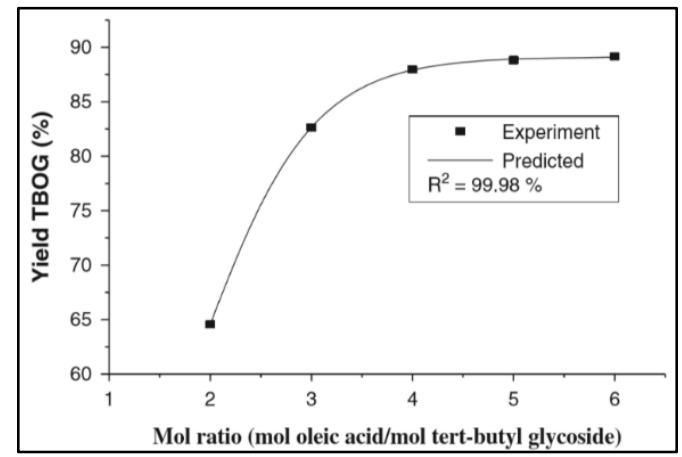

Fig. 1 The Correlation of Mole Ratio and The Yield of TBOG [15]

\section{B. The Effect of p-TSA Catalyst Percentage on Yield}

Based on [15] previous studies, the esterification process carried out at a mole ratio of 1: 4, variations in the amount of p-TSA catalyst, stirring $100 \mathrm{rpm}$, synthesis time about 4 hours, and temperature of $90^{\circ} \mathrm{C}$ (Fig. 2). Figure 2 shows the percent of catalyst variation from $1 \%$ to $2 \%$, giving an increase in yield. Increasing the catalyst percent can reduce the activation energy in the esterification reaction, so the reaction speed increases along with the synthesis results. When catalyst percent is increased by more than $2 \%$, the synthesis results decreased. It is because the addition of the catalyst percent will be dropping the $\mathrm{pH}$ and caused the reaction would be in very acidic conditions. It showed in $2 \%$ catalyst, and the reactants have a $\mathrm{pH}$ between 5-6. Whereas at 2,5-3\% catalyst, the reactants were at $\mathrm{pH} 2-4$. This decrease in $\mathrm{pH}$ will directly affect the quality of the reactants because the primary ingredient of TBOG surfactants is glucose. If glucose exposed to acid at high temperatures, it will sustain the degradation of hydrocarbon groups, so that the synthesis product will be damaged [18].

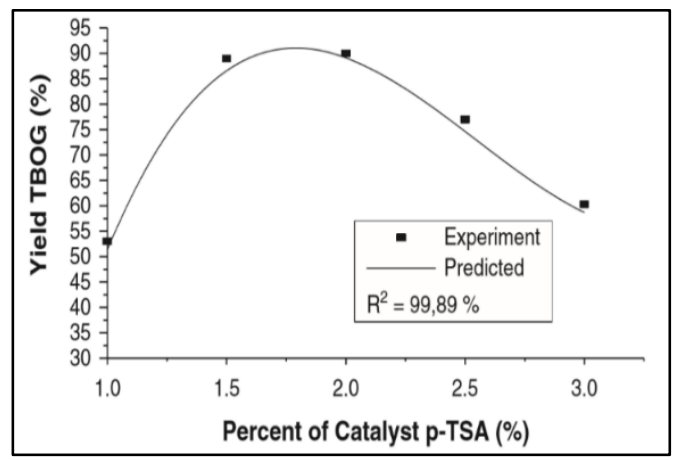

Fig. 2 The Correlation of Percent Catalyst p-TSA and The Yield of TBOG [15]

\section{The Effect of Temperature on Yield}

Based on previous research [15], the esterification process carried out at a catalyst mole ratio of 1: 4, $2 \%$ (w/w), stirring $100 \mathrm{rpm}$, synthesis time for about 4 hours, and variations in synthesis temperature (Fig. 3). Figure 3 shows the increase 
Vol. 6, Issue 12, December 2019

in synthesis results from $75^{\circ} \mathrm{C}$ to $90^{\circ} \mathrm{C}$. It is caused by the reaction speed, which is greatly influenced by the rise in reaction temperature, the pure vapor pressure of the component $\left(\mathrm{P}^{\mathrm{o}}\right.$ sat $)$, and the boiling point of the mixture of synthesized elements [20]. However, after the temperature exceeds $96^{\circ} \mathrm{C}$, a decrease in synthesis results occurs because after the temperature is above $90^{\circ} \mathrm{C}$, the operating conditions are above the boiling point of the component mixture. That causes caramelization of the glucose component, so the synthesis product begins to break down. For TBG esterification with oleic acid to form TBOG surfactants, the best conditions obtained at a mole ratio of 1: 4, catalyst $2 \%$, and the temperature of $90^{\circ} \mathrm{C}$ with a yield of $91,49 \%$.

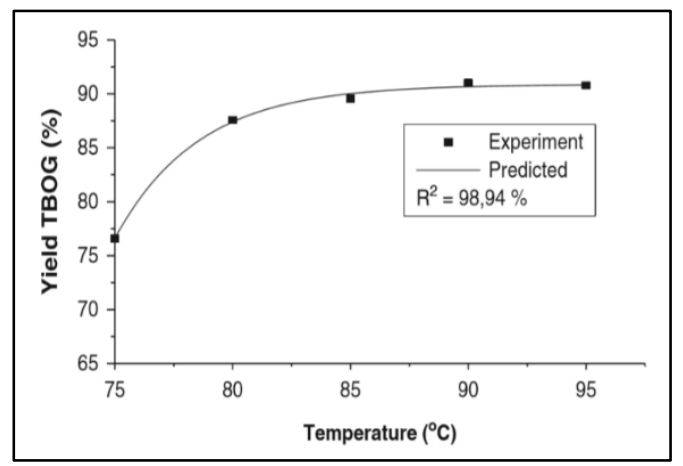

Fig. 3 The Correlation between Temperature and The Yield of TBOG [15]

\section{The FTIR analysis results for Ter-Butyl Oleil Glucoside Surfactant}

FTIR spectrum has several waves in the ether function group and the hydroxyl functional group. The formation of an ether group (C-O-C) indicates that the synthesis between the hydroxyl group of tert-Butyl Glucoside and fatty alcohols has formed, which means the structure of the hydrophobic group of APG surfactants has also been created. The OH group indicates the hydrophilic group from APG surfactant has formed. The best conditions for the TBG esterification process with oleic acid in developing a TBOG surfactant were at a mole ratio of $1: 4,2 \%$ catalyst, and the temperature of $90^{\circ} \mathrm{C}$ with a yield of $91,49 \%$. The results of the analysis of the TBOG surfactant structure group using FTIR (Fig. 4). Figure 4 shows that the correlation between wavelength and percent transmission will show different transmission peak points. It depends on the structural group in the compound (Table 1).

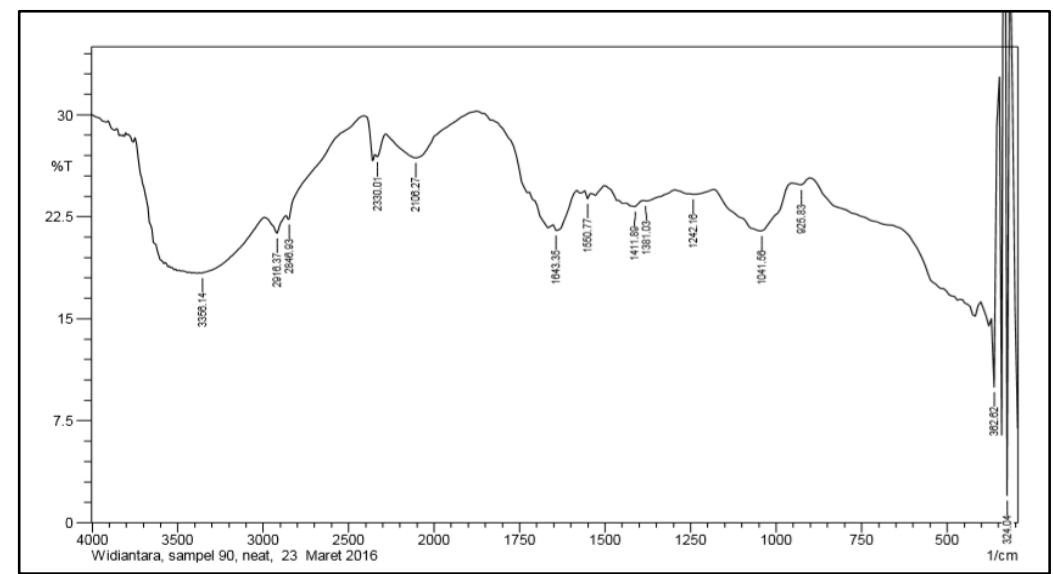

Fig. 4 The Correlation of Wavelengths and Percents of Transmission of FTIR TBOG

Table 1 shows that the wavelengths in the Ter-Butyl Oleil Glucoside molecule formed contain O-H groups, C-O-C groups, $-\mathrm{CH}_{2}$ groups, $-\mathrm{CH}_{3}$ groups, $\mathrm{C}-\mathrm{O}$ groups, and $\mathrm{C}=\mathrm{C}$ groups. Thus, it can show that the TBOG surfactant has formed in its reaction. 


\section{International Advanced Research Journal in Science, Engineering and Technology}

Vol. 6, Issue 12, December 2019

Table 1. The Characterization of TBOG Surfactant Functional Groups

\begin{tabular}{cccc}
\hline & \multicolumn{3}{c}{ Wavelength $\left(\mathbf{c m}^{-\mathbf{1}}\right)$} \\
\cline { 2 - 4 } $\begin{array}{c}\text { Functional } \\
\text { groups }\end{array}$ & Wavelength Range & $\begin{array}{c}\text { El-Sukkary dkk. } \\
\mathbf{( 2 0 0 8 )}\end{array}$ & $\begin{array}{c}\text { TBOG } \\
\text { Synthesis }\end{array}$ \\
\hline $\mathrm{O}-\mathrm{H}$ & $2.993,52-3.371,57$ & 3.200 & $3.356,14$ \\
$\mathrm{C}-\mathrm{O}-\mathrm{C}$ & $1.188,15-1.288,45$ & 1.152 & $1.242,16$ \\
$\mathrm{CH}_{2}$ & $1.388,75-1.435,04$ & 1.466 & $1.411,89$ \\
$\mathrm{CH}_{3}$ & $2.407,16-2.962,36$ & 2.961 & $2.846,93$ \\
$\mathrm{C}-\mathrm{O}$ & $956,69-1.180,44$ & 1.056 & $1.041,56$ \\
$\mathrm{C}=\mathrm{C}$ & $1.589,34-1.651,07$ & 1.635 & $1.643,35$ \\
\hline
\end{tabular}

\section{E. Models and Reaction Kinetics Parameters with and without the addition of Co-solvent}

\section{1) The Rate of Reaction Kinetics of TBOG Surfactant Formation}

The esterification reaction kinetics model between TBG and oleic acid viewed from the conversion of the product produced or the reduction in the concentration of the primary reactants per unit time. An overview of the reaction kinetics parameters includes the reaction order, the reaction rate constant $(\mathrm{k})$, and the activation energy (- $\left.\mathrm{E}_{\mathrm{a}}\right)$. The Surfactant synthesis results analyzed through quantitative testing with GC-MS tools. The esterification reaction of Oleic acid with tert-Butyl Glycosides is as follows:

\begin{tabular}{|c|c|c|c|c|c|}
\hline $\begin{array}{c}\mathrm{C}_{10} \mathrm{H}_{20} \mathrm{O}_{6} \\
(\mathrm{TBG})\end{array}$ & + & $\begin{array}{c}\mathrm{C}_{18} \mathrm{H}_{34} \mathrm{O}_{2} \\
\text { (Oleic Acid) }\end{array}$ & $\varlimsup_{\mathrm{P}=1 \mathrm{~atm} ; \mathrm{T}=90^{\circ} \mathrm{C}}^{\mathrm{p}-\mathrm{TSA}}$ & $\begin{array}{c}\mathrm{C}_{28} \mathrm{H}_{52} \mathrm{O}_{7} \\
\text { (TBOG) }\end{array}$ & + \\
\hline
\end{tabular}

The reaction above is a pseudo homogenous reaction because one of the reactants made excess (in this case, the oleic acid made excess). The kinetic model for the reaction approached through the kinetic model studied previously by de Jong [21] and Singh [19], where the research was the preparation of the kinetics model of the esterification reaction between myristic acid and the solvents of isopropanol, isobutanol, and methanol. The catalyst used is the p-TSA catalyst, sulfuric acid, and Amberlyst 15 solid catalyst. From the research, the reaction speed model obtained as follows:

$$
\begin{aligned}
& \mathrm{r}_{\mathrm{E}}=[\mathrm{cat}]\left(\mathrm{A}_{1}{ }^{\mathrm{o}} \exp ^{(-\mathrm{Ea} 1 / \mathrm{RT})}([\mathrm{Ao}]-[\mathrm{E}]) \cdot([\mathrm{Bo}]-[\mathrm{E}])-\mathrm{A}_{2}{ }^{\mathrm{o}} \exp ^{(-\mathrm{Ea} 2 / \mathrm{RT})}[\mathrm{E}]^{2}\right) \\
& \mathrm{r}_{\mathrm{E}}=[\mathrm{C}]\left(\mathrm{A}_{1}{ }^{\mathrm{o}} \exp ^{(-\mathrm{Ea} 1 / \mathrm{RT})}([\mathrm{Ao}]-[\mathrm{E}]) \cdot([\mathrm{Bo}]-[\mathrm{E}])-\mathrm{A}_{2}{ }^{\mathrm{o}} \exp ^{(-\mathrm{E} 2 / \mathrm{RT})}[\mathrm{E}]^{2}\right) \ldots
\end{aligned}
$$

The reaction kinetics model in equation (1) is a model for kinetics without the addition of co-solvent concentration, while equation (2) is a model for kinetics with the addition of co-solvent concentrations. The two reaction kinetics models above have four parameters, i.e : $\mathrm{A}_{1}{ }^{\circ}, \mathrm{A}_{2}{ }^{\mathrm{o}},-\mathrm{E}_{\mathrm{a} 1}$, $-\mathrm{E}_{\mathrm{a} 2}$. The four parameters are determined using Data Analysis Solver from Microsoft Excel 2016. The kinetics model is arranged based on the esterification reaction between TBG and oleic acid at variations in temperature $\left(75,90,92\right.$, and $\left.98^{\circ} \mathrm{C}\right)$, as well as variations in sampling time $(10,30,60,75$ and 100 minutes). The rate of formation of esterification product concentration $\left(\mathrm{r}_{\mathrm{E}}\right)$ using co-solvent and without co-solvent showed in Table 2 and Table 3.

\begin{tabular}{|c|c|c|c|c|c|c|c|c|}
\hline \multirow{4}{*}{ Minutes } & \multicolumn{8}{|c|}{ Temperatures $\left({ }^{\circ} \mathrm{C}\right)$} \\
\hline & \multicolumn{2}{|c|}{75} & \multicolumn{2}{|c|}{90} & \multicolumn{2}{|c|}{92} & \multicolumn{2}{|c|}{98} \\
\hline & $\mathrm{r}_{\mathrm{E}} /[\mathrm{C}]$ & $\mathrm{r}_{\mathrm{E}} /[\mathrm{C}]$ & $\mathrm{r}_{\mathrm{E}} /[\mathrm{C}]$ & $\mathrm{r}_{\mathrm{E}} /[\mathrm{C}]$ & $\mathrm{r}_{\mathrm{E}} /[\mathrm{C}]$ & $\mathrm{r}_{\mathrm{E}} /[\mathrm{C}]$ & $\mathrm{r}_{\mathrm{E}} /[\mathrm{C}]$ & $\mathrm{r}_{\mathrm{E}} /[\mathrm{C}]$ \\
\hline & Data & Model & Data & Model & Data & Model & Data & Model \\
\hline 10 & 0,794 & 0,806 & 1,085 & 1,109 & 1,326 & 1,376 & 0,506 & 0,612 \\
\hline 30 & 0,997 & 1,012 & 1,278 & 1,297 & 1,519 & 1,523 & 0,675 & 0,688 \\
\hline 60 & 1,232 & 1,246 & 1,519 & 1,576 & 1,760 & 1,809 & 0,940 & 0,951 \\
\hline 75 & 1,498 & 1,521 & 1,784 & 1,793 & 2,098 & 2,209 & 1,206 & 1,211 \\
\hline 100 & 2,046 & 2,067 & 2,339 & 2,427 & 2,652 & 2,871 & 1,760 & 1,795 \\
\hline$\%$ error & \multicolumn{2}{|c|}{1,342} & \multicolumn{2}{|c|}{2,343} & \multicolumn{2}{|c|}{4,073} & \multicolumn{2}{|c|}{5,289} \\
\hline Averages & \multicolumn{8}{|c|}{3,262} \\
\hline
\end{tabular}

Table 2. The rate of formation of the product concentration $\left(\mathrm{r}_{\mathrm{E}}\right)$ esterification uses co-solvent 


\section{International Advanced Research Journal in Science, Engineering and Technology}

Vol. 6, Issue 12, December 2019

Table 3. The rate of formation of esterification product concentration $\left(\mathrm{r}_{\mathrm{E}}\right)$ without co-solvent

\begin{tabular}{|c|c|c|c|c|c|c|c|c|}
\hline \multirow{3}{*}{ Minutes } & \multicolumn{8}{|c|}{ Temperatures $\left({ }^{\circ} \mathrm{C}\right)$} \\
\hline & \multicolumn{2}{|c|}{75} & \multicolumn{2}{|c|}{90} & \multicolumn{2}{|c|}{92} & \multicolumn{2}{|c|}{98} \\
\hline & $\begin{array}{c}\mathrm{r}_{\mathrm{E}} /[\mathrm{cat}] \\
\text { Data }\end{array}$ & $\begin{array}{c}\mathrm{r}_{\mathrm{E}} /[\mathrm{cat}] \\
\text { Model }\end{array}$ & $\begin{array}{c}\mathrm{r}_{\mathrm{E}} /[\mathrm{cat}] \\
\text { Data }\end{array}$ & $\begin{array}{c}\mathrm{r}_{\mathrm{E}} /[\mathrm{cat}] \\
\text { Model }\end{array}$ & $\begin{array}{c}\mathrm{r}_{\mathrm{E}} /[\mathrm{cat}] \\
\text { Data }\end{array}$ & $\begin{array}{c}\mathrm{r}_{\mathrm{E}} /[\mathrm{cat}] \\
\text { Model }\end{array}$ & $\begin{array}{c}\mathrm{r}_{\mathrm{E}} /[\mathrm{cat}] \\
\text { Data }\end{array}$ & $\begin{array}{c}\mathrm{r}_{\mathrm{E}} /[\mathrm{cat}] \\
\text { Model }\end{array}$ \\
\hline 10 & 0,0057 & 0,0063 & 0,0100 & 0,012 & 0,01337 & 0,0149 & 0,0063 & 0,0068 \\
\hline 30 & 0,0078 & 0,0089 & 0,0107 & 0,012 & 0,01454 & 0,0163 & 0,0095 & 0,013 \\
\hline 60 & 0,0106 & 0,011 & 0,0149 & 0,0151 & 0,01746 & 0,0180 & 0,0111 & 0,0127 \\
\hline 75 & 0,0145 & 0,0152 & 0,0197 & 0,0213 & 0,02322 & 0,0243 & 0,0164 & 0,0182 \\
\hline 100 & 0,0238 & 0,0241 & 0,0249 & 0,0278 & 0,02840 & 0,0290 & 0,0232 & 0,0265 \\
\hline \%error & \multicolumn{2}{|c|}{6,89} & \multicolumn{2}{|c|}{10,65} & \multicolumn{2}{|c|}{6,68} & \multicolumn{2}{|c|}{16,87} \\
\hline Averages & \multicolumn{8}{|c|}{10,278} \\
\hline
\end{tabular}
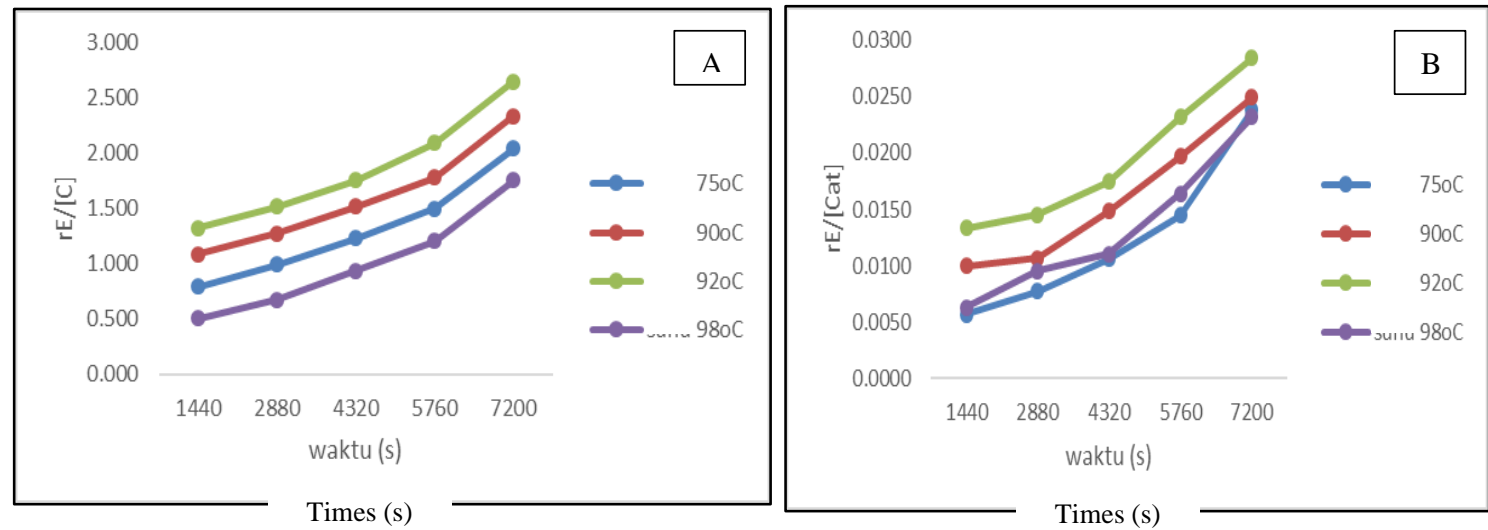

Fig. 5 Relationship between $\mathrm{r}_{\mathrm{E}} /[\mathrm{C}]$ vs time (s): (A) Conditions using Co-Solvent); (B) Without using Co-Solvent

The reaction order is the sum of the reactant concentration exponents in the reaction rate law. The determination of the reaction order is based on the highest coefficient of determination $\left(\mathrm{R}^{2}\right)$ and also the smallest percentage $(\%)$ error of value. The kinetics model that used in this study refers to the second-order reaction kinetics model that Singh [19], de Jong [21], and Yalçinyuva [22] had previously studied. Based on data from Tables 2 and 3, which show that the rate of formation of the results of the TBOG surfactant synthesis $\left(\mathrm{r}_{\mathrm{E}}\right)$ using additional co-solvents is higher than the rate of formation of the synthesis results without co-solvent. The percentage of error from the kinetics model using the co-solvent is also smaller than the kinetics model without co-solvent. The addition of co-solvent has a considerable influence on the speed of the esterification reaction between oleic acid and TBG. Organic co-solvent works optimally with an acid catalyst (p-TSA) because of its hydrophilic and hydrophobic properties, which can reduce the surface tension between the oleic acid layer and TBG.
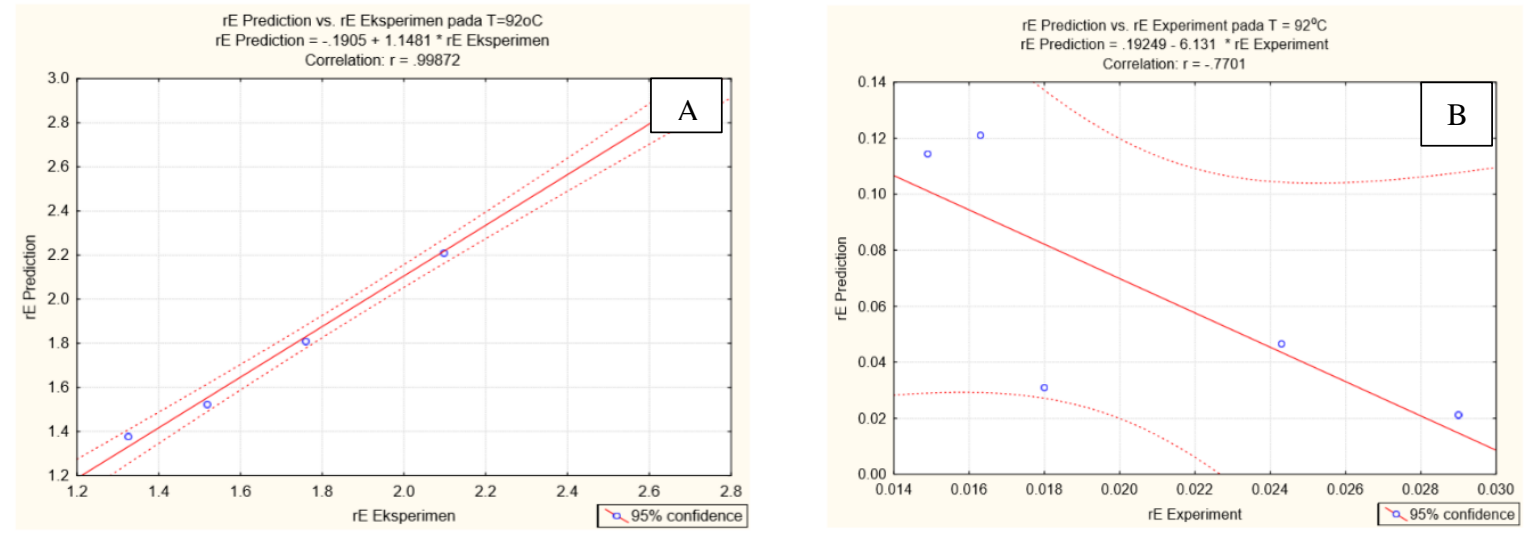

Fig. 6 The Relationship of The $\mathrm{r}_{\mathrm{E}}$ Concentration of The Calculated (predicted) Kinetic Model with The Experimental Kinetics Model (A) using Co-Solvent; (B) without Co-Solvent ((-) $\mathrm{r}_{\mathrm{E}}$ calculation compared to the experimental rE; (---) error limit) 


\section{International Advanced Research Journal in Science, Engineering and Technology}

Vol. 6, Issue 12, December 2019

Besides, the co-solvent is also able to minimize the production of $\mathrm{H}_{2} \mathrm{O}$ when the esterification reaction is in progress. Organic co-solvents can also reduce the viscosity of oleic acid, thereby increasing the solubility of glucose alcohol in oleic acid [23], [24].

Figure 6 shows the relationship between TBOG surfactant concentrations produced through prediction models and experimental results models. Concentration data took from Table 2 at $92^{\circ} \mathrm{C}$ operating conditions for the esterification reaction kinetics model using co-solvent, and Table 3 at $92^{\circ} \mathrm{C}$ operating conditions for the esterification reaction kinetics model without co-solvent. All data is processed using Statistica 8.0 software to find the best correlation between the prediction model (calculation) with the experimental model through the Residual Regression Design method.

Figure 6 (A) and 6 (B) showed that the correlation between TBOG surfactant concentration with the addition of cosolvent is better than TBOG surfactant concentration without co-solvent. Correlation value (r) for predicted $\mathrm{r}_{\mathrm{E}}$ compared to $r_{E}$ of TBOG surfactant experiments with the addition of co-solvent is 0,99872 . The correlation value shows the suitability of the results from the predicted kinetic model with the results of the experiments in the laboratory [21]. The dotted line is the error limit obtained from twice the standard deviation. Statistically, in a normal distribution, about $95 \%$ of the value in this area. As can be seen in Figure 6 (A), almost all values are within these limits. It shows that the model is accurate enough to describe the reaction kinetics based on experimental data.

\section{The Kinetics Parameter}
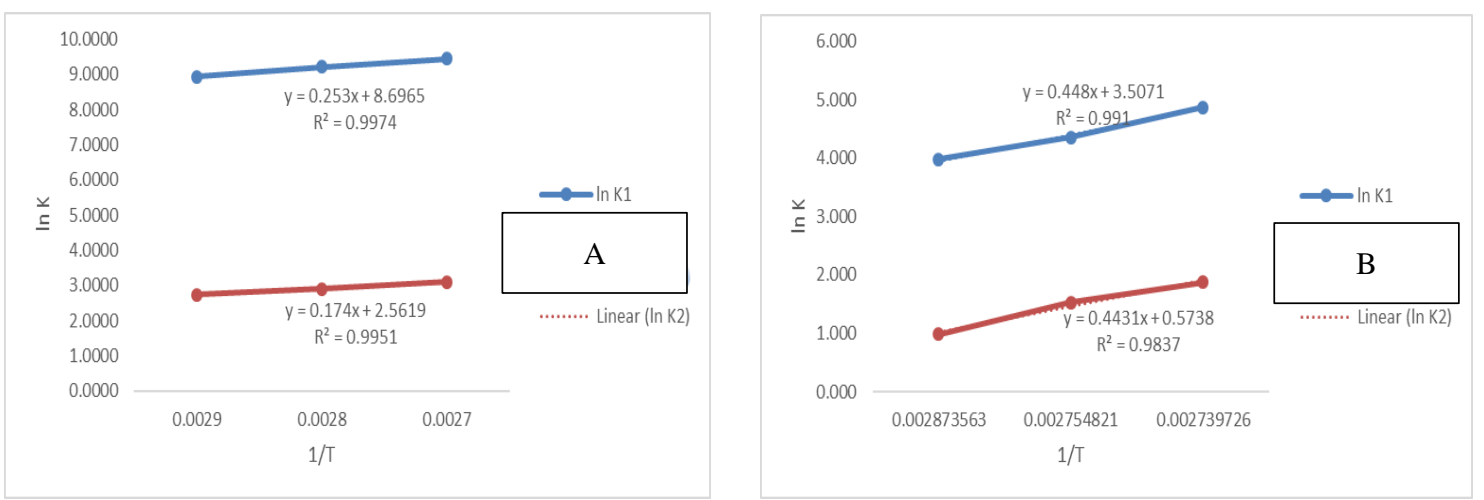

Fig. 7 The Relationship between ln k vs 1/T: (A) co-solvent; (B) non-co-solvent

The coefficient of determination $\left(\mathrm{R}^{2}\right)$ is the ratio of variance in prediction models and variance in experimental data. If the coefficient of determination $\left(\mathrm{R}^{2}\right)$ is close to 1 , the value predicted by the model is the same as the experimental value. Higher $\mathrm{R}^{2}$ values for the esterification reaction between TBG and oleic acid through the addition of co-solvent provide a better description of the reaction kinetics model without the addition of co-solvent [21]. The actual reaction rate constant (k) at the appropriate reaction temperature depends mostly on activation energy. Therefore, the reaction rate constants (k) for reversible reactions cannot be compared with each other, because the activation energy is different [25], [22].

Table 4. The Reaction rate constant vs temperatures (co-solvent)

\begin{tabular}{cccc}
\hline $\begin{array}{c}\text { Temperatures } \\
(\mathrm{K})\end{array}$ & ln $\mathrm{k}_{1}$ & $\ln \mathrm{k}_{2}$ & $1 / \mathrm{T}$ \\
\hline 348 & 8,94 & 2,74 & 0,0029 \\
363 & 9,21 & 2,89 & 0,0028 \\
365 & 9,44 & 3,09 & 0,0027 \\
\hline
\end{tabular}

Table 5. The Reaction rate constant vs temperatures (without co-solvent)

\begin{tabular}{cccc}
\hline $\begin{array}{c}\text { Temperatures } \\
(\mathrm{K})\end{array}$ & $\ln \mathrm{k}_{1}$ & $\ln \mathrm{k}_{2}$ & $1 / \mathrm{T}$ \\
\hline 348 & 3,98 & 0,98 & 0,0029 \\
363 & 4,35 & 1,52 & 0,0028 \\
365 & 4,88 & 1,87 & 0,0027 \\
\hline
\end{tabular}

Based on data Tables 4 and 5, it shows that as the esterification temperature increases, the reaction rate constant $(\mathrm{k})$ increases because the reaction rate is proportional to the reaction temperature. Collisions between particles being perfect 


\section{International Advanced Research Journal in Science, Engineering and Technology}

Vol. 6, Issue 12, December 2019

and the activation energy of molecules become more quickly achieved due to an increase in reaction temperature. In this study, the temperature was limited to $92^{\circ} \mathrm{C}$. It aims to avoid the degradation of TBG reactants [26], [27], [16]. These results are also supported by research conducted by Yalcinyuva [22].

Calculation of the activation energy value $\left(-\mathrm{E}_{\mathrm{a}}\right)$ and the collision factor $\left(\mathrm{k}_{\mathrm{o}}\right)$ completed mathematically. Activation energy is the minimum energy needed by reactants to react [28]. The equation for settlement and calculation (- $\left.\mathrm{E}_{\mathrm{a}}\right)$ and $\mathrm{k}_{\mathrm{o}}$ follow the Arrhenius equation, which is $\mathrm{k}=\mathrm{k}_{\mathrm{o}} \exp (-\mathrm{Ea} / \mathrm{RT})$. The equation has an identical form to the equation of the line $\mathrm{y}=$ $m x+C$ with the slope value is $-E_{a} / R$ while the intercept value is $\ln \mathrm{k}_{\mathrm{o}}$. Slope and intercept data for determining the kinetic reaction parameters are obtained from the linear equation shown in Figures 7 (A) and 7 (B). The value of the kinetics reaction parameters obtained can see in Table 6.

Table 6. Kinetic Reaction Parameters for Esterification Reactions with Co-solvent and non-Co-solvent

\begin{tabular}{ccc} 
Parameter & Co-Solvent & Non Co-solvent \\
\hline $\mathrm{A}_{1}{ }^{\mathrm{o}}$ & $6 \times 10^{3}$ & $3,3 \times 10^{1}$ \\
$\mathrm{~A}_{2}{ }^{\mathrm{o}}$ & $1,3 \times 10^{1}$ & 1,5 \\
$-\mathrm{Ea}_{1}$ & $-2.103,44$ & $-3.683,93$ \\
$-\mathrm{Ea}_{2}$ & $-1.446,63$ & $-4.770,57$ \\
\hline
\end{tabular}

From the Table 6 data, the reaction rate kinetics model with the kinetic parameter values are :

$$
\begin{aligned}
& \left.r_{\mathrm{E}}=[\mathrm{cat}] 3,3 \times 10^{1} \exp ^{(-3.683,93 / \mathrm{RT})}([\mathrm{Ao}]-[\mathrm{E}]) \cdot([\mathrm{Bo}]-[\mathrm{E}])-1,5 \exp ^{(-4.770,57 / \mathrm{RT})}[\mathrm{E}]^{2}\right) \ldots \ldots \ldots \\
& \left.\mathrm{r}_{\mathrm{E}}=[\mathrm{C}] 6 \times 10^{3} \exp ^{(-2.103,44 / \mathrm{RT})}([\mathrm{Ao}]-[\mathrm{E}]) \cdot([\mathrm{Bo}]-[\mathrm{E}])-1,3 \times 10^{1} \exp ^{(-1.446,63 / \mathrm{RT})}[\mathrm{E}]^{2}\right) \ldots \ldots
\end{aligned}
$$

The equation (3) is the kinetic equation for the esterification reaction of TBG and oleic acid using the p-TSA catalyst without the addition of co-solvent. Then, the equation (4) is the kinetics equation for the esterification reaction of TBG and oleic acid using the p-TSA catalyst with the addition of co-solvent.

\section{IV.CONCLUSION}

The TBOG surfactant obtained has a yellow color quality, the best requirements obtained at mole ratio of 1: 4. As much as $91,49 \%$ of the results obtained from $2 \%$ catalyst and temperature of $90^{\circ} \mathrm{C}$. From FTIR analysis, TBOG molecules formed with different wavelengths are $\mathrm{O}-\mathrm{H}$ groups, $\mathrm{C}-\mathrm{O}-\mathrm{C}$ groups, $\mathrm{CH}_{2}$ groups, $\mathrm{CH}_{3}$ groups, $\mathrm{C}-\mathrm{O}$ groups, and $\mathrm{C}=\mathrm{C}$ groups, all of which look right in the reaction. Esterification reaction between TBG with oleic acid is reversible and a second-order reaction. The suitability model of product formation reaction kinetics $\left(\mathrm{r}_{\mathrm{E}}\right)$ further discusses the reaction kinetics model through modification of the co-solvent addition with a comparison value of 0,99872 . The reaction kinetics

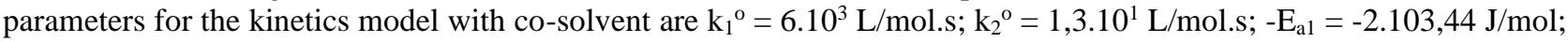
$-\mathrm{E}_{\mathrm{a} 2}=-1.446,63 \mathrm{~J} / \mathrm{mol}$, and the kinetics reaction parameters for the kinetics model without co-solvent addition are $\mathrm{k}_{1}{ }^{\mathrm{o}}=$ 3,3.10 ${ }^{1} \mathrm{~L} / \mathrm{mol} . \mathrm{s} ; \mathrm{k}_{2}{ }^{\mathrm{o}}=1.5 \mathrm{~L} / \mathrm{mol} . \mathrm{s} ;-\mathrm{E}_{\mathrm{a} 1}=-3.683,93 \mathrm{~J} / \mathrm{mol} ;-\mathrm{E}_{\mathrm{a} 2}=-4.770,57 \mathrm{~J} / \mathrm{mol}$.

\section{REFERENCES}

[1]. M. M. El-Sukkary, N. A. Syed, I. Aiad, and W. I. M. El-Azab, J. Surf. Detergents 11, 129 (2008)

[2]. A. Corma, S. Iborra, S. Miquel, and J. Primo, J. Catalysis 161, 713 (1996).

[3]. O. Kirk, F. D. Pedersen, and C. C. Fuglsang, J. Surf. Detergents 1, 37 (1998).

[4]. D. Coulon, A. Ismail, M. Girardin, and M. Ghoul, J. Mol. Catal. B: Enzym. 5, 45 (1998).

[5]. K. J. Holmberg, B. Jönsson, B. Kronberg, and B. Lindman, Surfactants and Polymers in Aqueous Solution, $2^{\text {nd }}$ ed., John Wiley, Chichester, New York (2003).

[6]. A. I. Suryani, S. Dadang, and A. S. Tjokrowardojo, Sintesis Alkil Poliglikosida Berbasis Alkohol Lemak dan Pati Sagu untuk Formulasi Herbisida, IPB, Bogor (2008).

[7]. E. Hambali, P. Permadi, Y. Astuti, A. Suryani, M. Rivai, Padil, and C. Prihartono, Pemilihan Konsentrasi Katalis PTSA untuk Sintesis Surfaktan Alkilpoliglikosida dari Palm Fatty Alcohol (C16_dan Glukosa Cair 85\% dari Singkong untuk Aplikasi EOR, Prosiding InsSINas, EN, November (2012), pp. 136-140.

[8]. Adisalamun, D. Mangunwidjaya, A. Suryani, T. C. Sunarti, and A. Arkeman, J. Teknol. Industr. Pertanian 22, 51 (2012).

[9]. P. Clapés and I. M. Rosa, Biocatalysis and Biotransformation 20, 215 (2002).

[10]. M. J. Rosen, Surfactants and Interfacial Phenomena, 3rd edn., John Wiley and Sons, Inc., New Jersey (2004), pp. 303-320.

[11]. P. Becher, Hydrophile-Lipophile Balance; History and Recent Developments Langmuir Lecture Dispersion Science and Technology, New York (1984), Vol. 5, pp. 81-96.

[12]. A. M. Ware, J. T. Waghmare, and S. A. Momin, J. Disp. Sci. and Technol. 28, 437 (2007).

[13]. J. Xu, A. Yin, J. Zhao, D. Li, and W. Hou, J. Phys. Chem. B 117, 450 (2013).

[14]. O. D. Velev, T. D. Gurkov, and R. P. Borwankar, J. Colloid Interface Sci. 159, 497 (1993).

[15]. Pawignya, H., Kusworo, T.D., Widiantara, I.G.N., Pramudono, B.(2017). Synthesis Tert-Butyl Oleyl Glycosides Surfactant from Esterification Tert-Butyl Glycosides with Oleic Acids. Advanced Science Letters : 5716-5719 


\title{
International Advanced Research Journal in Science, Engineering and Technology
}

\author{
Vol. 6, Issue 12, December 2019
}

[16]. Pawignya, H., Kusworo, T.D., Pramudono, B.(2018). Optimization for Production Tert-Butyl Oleyl Glycoside Nonioic Surfactant Using Response Surface Methodology. AJChe : 62-69.

[17]. Connors, K.A. (1990). Chemical kinetics : the study of reaction rates in solution. Responsibility: Imprint: New York : VCH

[18]. Yeramian, A.A., Cunningham, R.E., Gottifredi, J.C.(1968). Vapor-phase reactions catalyzed by ion exchange resins: I. Isopropanol dehydration. Journal of Catalysis

[19]. Singh, N., Kumar, R., Sachan, P.K. (2013). Kinetic Study of Catalytic Esterification of Butyric Acid and Ethanol over Amberlyst 15. Research Article. Hindawi Publishing Corporation : ISRN Chemical Engineering.

[20]. Wang, Q., Wang,D., Wang, H., Xu, C.(2018). Influence of alkyl polyglucoside and fatty alcohol ether sulfate on the foaming and wetting properties of sodium dodecyl benzene sulfonate for mine dust control. Journal of Powder Technology. 345: 91-98

[21]. de Jong, M.C., Feijt, R., Zondervan, E., Nijhuis, T.A., de Haan, A.B. (2009). Reaction kinetics of the esterification of myristic acid with isopropanol and n-propanol using p-toluene sulphonic acid as catalyst. Journal of Applied Catalysis A. General. $365: 141-147$.

[22]. Yalcinnyuva, T., Deligöz, H., Boz, I., Gürkaynak, M.A. (2007). Kinetics and Mechanism of Myristic Acid and Isopropyl Alcohol Esterification Reaction with Homogeneous and Heterogeneous Catalysts. International Journal of Chemical Kinetics. Wiley InterScience.

[23]. Othmer, D.F., Rao, S.A.(1950). Kinetic Study for the esterification of Oleic Acid with Methanol using pTSA and H2SO4 as Catalyst.Ind. Eng. Chem. $42: 1912-1919$

[24]. Lacaze-Dufaure, C., Mouloungui, A.(2010). Kinetic Study for the esterification of Oleic Acid with 2-ethylhexanol using pTSA as Catalyst. Appl. Catal. A: Gen. $204: 223-227$

[25]. Popken, T., Gotze, L., Gmehling, J. (2006). Reaction Kinetics and Chemical Equilibrium of Homogeneously and Heterogeneously Catalyzed Acetic Acid Esterification with Methanol and Methyl Acetate Hydrolysis. Ind. Eng. Chem. Res. 39 : 2601-2611.

[26]. Sembiring, H. (2007). Pembuatan Surfaktan tert-Butil Galaktosida Melalui Reaksi Asetalisasi Galaktosa dengan tert-Butanol. Jurnal Penelitian MIPA (1).

[27]. Rachim, P.F., Mirta, E.L., Thoha, M.Y. (2012). Pembuatan surfaktan natrium lignosulfonat dari tandan kosong Kelapa Sawit Dengan Sulfonasi Langsung. 18(1) : 41-46.

[28]. Clark, J.H.(2002). Handbook of Green Chemistry and Technology. Blackwell. 